\title{
Financial Performance As It Relates To Pollution Control: An Empirical Analysis
}

Jeffrey L. Decker (E-mail: jdecker@hawaii.edu), University of Hawaii at Hilo, USA Terrance Jalbert (E-mail: jalbert@hawaii.edu), University of Hawaii at Hilo, USA

\begin{abstract}
This paper explores the firm-level characteristics that explain pollution emissions during 19881996. Differences in pollution approach between different types of firms provide an unique research setting to investigate how firms with favorable environmental reputations compare to firms with unfavorable environmental reputations regarding emissions what firm characteristics are related to environmental performance, and how firms respond to regulation changes. The paper is the first to use emissions information from a non-financial source to analyze differences between firms to changes in regulatory requirements. The results provide clear evidence that green firms behave markedly different, have different firm characteristics, and react to changes in regulatory regime in different ways than their non-green counterparts.
\end{abstract}

\section{Introduction}

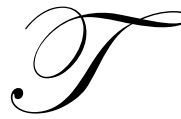

he impact of environmental concerns on U.S. businesses has grown dramatically over the past 20 years. Firms have responded to changes in environmental regulations and changes in public opinion in various ways. Understanding firm response to increased environmental scrutiny and the affect on firm profitability and firm characteristics is important in assessing overall performance. Since this type of non-financial information is becoming increasingly important, the accounting profession has been incorporating non-financial performance measures into traditionally financially oriented reports (Kaplan and Norton 1996; Ilinitch et al. 1998). This study is the first to use emissions information from a non-financial source to analyze differences between firms to changes in regulatory environment. In addition, the paper advances the literature related to several different research streams.

Firms respond to the increase in public scrutiny of their pollution control progress in various ways. Some firms take a proactive approach and develop positive environmental reputations. Others take a reactive approach and are seen as having unfavorable environmental reputations. These differences in pollution approach between different types of firms provide a unique research setting to investigate how firms with favorable environmental reputations compare to firms with unfavorable environmental reputations regarding emissions and what firm characteristics are related to environmental performance? This study extends the literature on several fronts. It extends the literature on how the general reputation of firms affects financial performance by simultaneously incorporating non-financial data and by focusing on the environmental reputation of firms. It extends studies of environmental reputation by utilizing a different measure of green or non-green. It extends those studies that have utilized the Toxic Release Inventory (TRI) database by lengthening the time frame of the analysis, examining multiple industries and incorporating total emissions data rather than only one type of emissions. Finally, by segregating the data into two sub-samples the impact of regulatory change on firm behavior is examined.

\section{Overview And Literature Review}

Individuals have become increasingly pro-environment in their opinions. Almost two-thirds of Americans believe that pollution is negatively affecting their lives. In the mid-eighties the percentage was less than 50 percent 
(Shrivastava 1996). Recycling continues to grow, with consumers using products with less packaging and more recycled materials. Top managers at some firms embrace environmental issues and promise to incorporate these concerns into their strategic planning process. Others continue to view the environment as a resource to be used in production, while conforming to the most minimal levels of environmental compliance allowable (Shrivastava 1996).

Managers and firms are driven by economic incentives. As the concern for the environment grows, environmental issues have become part of the company's economic decision-making process. Firms that are seeking to develop a green strategy do so because they benefit from being green. These benefits can stem from reputational effects, reduced operating costs, reduced regulatory penalties or other effects. The reputational effects of being green can increase sales to consumers who make choices based on a firms' environmental policy/products. Given similar companies with similar products, shareholders who use environmental criteria in their investment decisions choose firms with favorable environmental reputations (Bhat 1998). If investors make decisions on this basis, the effect may be a reduced cost of capital for green firms. Equipment purchases can increase or decrease a company's efficiency. Purchasing pollution-reducing equipment may cost more at the outset, but often pays for itself in reduced waste, and costs throughout its useful life. In most cases, modern equipment is more efficient in reducing waste than previous generation equipment (Thomas 1995). Firms, and more importantly top management, are increasingly being held liable for violating pollution laws. Sentencing senior executives to prison has changed the causal attitude to pollution control once held by many top managers (BusinessWeek 1990).

The use of reputation as a part of a company's strategic plan is not new. Firms have long sought an image that would reflect well upon their operations. Many firms have spent years developing quality or value based reputations that would attract customers and investors to their companies. Despite their original strategic focus, companies frequently find that they cannot maintain their overall favorable image without also addressing the environmental impact of their operations. Few, if any, firms want to be labeled "anti-environmental." In fact, many Fortune 1000 firms spend millions of dollars trying to foster an environmentally friendly image (Prokop 1992). For many of these firms, it is only an attempt to confuse the public into believing that the firm's environmental record is better than it really is. For others, it represents an opportunity to seize a competitive advantage by taking a proactive approach to environmental issues. The real distinction is whether firms with favorable environmental reputations are really more environmentally friendly than other firms. If so, are there positive financial returns associated with a positive environmental reputation? If there are positive economic rents being obtained by firms based on their positive environmental reputations, these will provide incentives that may motivate other firms to lessen their impact on the environment.

The evidence concerning the connection between the general reputation of the firm and economic profitability appears to be positive. Herremans et al. (1993) find that U.S. manufacturing companies with favorable reputations outperform companies with unfavorable reputations over a 5-year period (1982-1986). He finds higher profitability as well as lower risk for firms with better reputations. Using profitability and emissions measures, this study extends the above study by focusing on environmental reputation, specifically by comparing a group of firms with favorable environmental reputations to a group of firms with unfavorable environmental reputations.

Russo and Fouts (1997) analyze environmental performance in high-growth firms, finding that "green" firms have higher economic performance. They compare firms that rely on short-term, end-of-pipe pollution control (non-green) to firms that have a strategy of focusing on pollution prevention (green). Russo and Fouts utilize ROA as the dependent variable in an equation that includes firm growth rate, advertising intensity, firm size, capital intensity and environmental ranking of firms. They find that environmental reputation, as measured by environmental ranking, is related to firm profitability. This study builds on Russo and Fouts (1997) by using a different sample of firms labeled green and non-green to examine profitability differences, it also compares the relationship of economic performance across different regulatory regimes.

The most recent research regarding non-performance data resulted in mixed findings concerning the value relevance of non-performance measurements. Gilley et al. (2000) performed an event study where environmental announcements in the Wall Street Journal were divided into process-driven and product-driven announcements. 
Using a two-day window, they compared stock price information before and after the announcement. Comparing a broader selection of firms than that used in previous studies, their sample included sixteen industries. They find no overall effect of announced environmental initiatives on stock returns. However, they did find that investors reacted more positively to announcements of product-driven environmental initiatives than to process-driven ones. The measure of environmental reputation and environmental initiatives published in the Wall Street Journal and used by Gilley et al. (2000) are over simplified. In this study, rankings of firms based on environmental reputation by mutual fund companies are used as a stronger measure of firms' environmental performance. This ranking takes into account firms recognized by financial markets as having unfavorable environmental reputations.

The introduction of the Toxic Release Inventory (TRI) database in 1987 provides new pollution data to researchers. Jaggie and Freedman (1992) examine pollution performance and its effects on economic and market performance in the pulp and paper industry. They find that green firms are less profitable and have lower stock prices than non-green firms. This finding raises the question of why firms would choose to be green. Limitations to this study include analysis of only one industry, the use of only water pollution data and reporting biases of firms filing with the EPA. In this study, total emissions are examined from a sample of firms in various manufacturing industries. The reporting bias may still be present since these firms' self-report emissions data. However, EPA officials, state officials and others audit facilities check for compliance of the reported TRI data thus, increasing the incentives for all firms to report data as accurately as possible. In addition, this study lengthens the time frame of the analysis by using nine years of data from the TRI database (1988-1996), which allows for improved analysis over time.

The extent to which environmental regulations have been implemented and reauthorized has changed with Presidential Administrations. During the Reagan and Bush Administrations, political changes slowed the reauthorization of many environmental statutes. The Bush Administration stated two main objectives for the environment: 1) To ensure environmental issues jeopardizing public health were addressed, and 2) to ensure that industry remained competitive in national and international markets. Many environmentalists believe that objective two was the real driver behind environmental programs during the Bush years with objective one relegated to a secondary status (Thomas 1995). President Clinton adopted various programs to address environmental issues at the start of his administration in 1993. Funding for the Environmental Protection Agency (EPA) was increased and the EPA was charged with incorporating pollution prevention in all its programs, regulations, enforcement activities, and negotiations (Thomas 1995). While states were primarily responsible for monitoring both state and federal regulations in the 1980's and early 1990's, the EPA reestablished its position as the national environmental protector under the Clinton Administration. In this paper, we extend the literature by segregating the sample into two subsamples to identify how these regulatory regime changes impacted firm behavior.

This paper advances the literature on several fronts. First, it extends the literature on the general reputation of firms on financial performance by simultaneously incorporating non-financial data and by focusing on the environmental reputation of firms. Second, we extend the studies of environmental reputation by utilizing a different measure of green or non-green. Third, we extend those studies that have utilized the TRI database by extending the time frame of the analysis, examining multiple industries and incorporating total emissions data rather than only one type of emissions. Finally, the sample is segregated into two sub-samples that correspond with the current Presidential Administration. By doing so, the impact changes in regulatory regime on firm behavior can be examined.

\section{Sample Selection}

In this study a sample of sixty firms are examined. Thirty green firms are compared to a sample of thirty non-green firms from 1988 through 1996. The first data collection task was to identify a group of green firms and a group of non-green firms. Once the two groups of firms were identified, annual financial data for each firm was obtained from the Compustat data files. Finally, annual TRI data was obtained for each firm in the sample from the Environmental Protection Agency. 
No consensus exists on what constitutes "green" or how firms should be classified as green or non-green. The financial market utilizes various methods to consider whether a company has a positive, neutral, or negative environmental reputation. One way to evaluate a company is to obtain an environmental annual report. Firms are increasingly issuing such reports, mostly for public relations purposes; however, in some cases they provide information relating to serious environmental evaluation. Some environmental groups such as Mother Earth publish lists of companies that, based on their measurements, have serious pollution problems. Other assess a firm's commitment to the environment based on whether the firm embraces the principles issued by the Coalition for Environmentally Responsible Economics (CERES). CERES was founded in 1989 by members from various public interest groups, environmental groups and social investors. While companies have no legal obligations to follow the CERES principles, many have adopted one or more of the principles (Prokop 1992).

While certain environmental groups such as Mother Earth have constructed lists of firms that perform poorly on one or more environmental criteria, these lists do not include any market determined basis for choosing a firm as green or non-green. In this study, mutual fund portfolios are used to identify green and non-green firms. These portfolios are market determined and thus are expected to be free from bias. The group of thirty green firms were randomly selected from the Domini Social Index which is a list of companies with favorable environmental reputations compiled by the Domini Mutual Fund Company. The group of thirty non-green firms were randomly selected from a list of companies with unfavorable environmental reputations compiled by SRI World Group, Inc. While these indices do not include all firms in the United States, they do represent a cross-sectional variety of manufacturing firms and are believed to be a representative sample. The firms cross eight different two-digit SIC industry groupings. The firms were compared to partial listings from other organizations for conflicting ratings. None were found.

The Domini Social Index purports to supply suitable information for socially responsible investors. Kinder, Lydenberg, Domini and Co, created the index in May of 1990. They reviewed areas of concern for the social investor, avoiding companies involved with alcohol, tobacco, gambling, nuclear power or military weapons. They also reviewed performance according to several environmental indicators, thereby assuring firms included in the index are proactive in promoting environmental controls. For environmental ratings, Domini considers pollution prevention programs, in-house recycling, contributions, and other indicators that suggest an environmentally proactive company. This approach to investing promoted by the Domini Social Index is termed a "Positive" or "affirmative" screening process for choosing suitable companies for investment (Domini 2000).

SRI World Group Inc. focuses on environmental and other social parameters in developing its investment portfolio. Like Domini, SRI World Group Inc. screens firms for environmental performance. Unlike Domini, SRI World Group lists firms that have major problems or concerns in any aspect of the environmental arena allowing investors to employ a "negative' or "avoidance" screening of firms. SRI World Group, Inc. analyzes the environmental commitment of firms to determine whether they are acceptable for inclusion in an environmentally focused financial portfolio. Firms with major environmental problems such as excessive waste, inefficient design of products and major environmental accidents are considered to be non-green in their commitment to the environment.

Congress passed the Superfund Amendments and Reauthorization Act in 1986. This act buttressed EPA authority to protect the environment, with the Emergency Planning and Community Right-To-Know Act (EPCRA). The main goals of EPCRA included the following 1) Development of state and local emergency planning organizations, 2.) General notification by high-risk industries to local emergency bodies for planning purposes, 3) Notification by industrial plants of any emergency involving certain hazardous materials, and 4) Two annual reporting requirements for hazardous chemical inventories and toxic chemical release inventories (TRI) (Thomas 1995). The fourth goal of EPCRA, the Toxic Chemical Release Inventories (TRI), required firms to report their operations' emissions to the EPA. Annual data from these TRI reports is collected for each firm in the sample from 1988-1996. 


\section{Hypothesis Development And Results}

The data analysis begins by providing univariate statistics regarding the data. Descriptive statistics of the data used in this study are presented in Table 1. The data is segregated into two sub-samples that correspond to the first Bush Administration and the Clinton Administration. The variables are defined as follows:

$\begin{array}{ll}\text { Total Emissions } & =\text { Annual Total Emissions for firm, } \\ \text { ROS } & =\text { Return on Sales, } \\ \text { Sales } & \text { = Sales in dollars per year, } \\ \text { Debt/Assets } & \text { = Interest Payment measure total debt divided by total assets, } \\ \text { \% Change Emissions } & \text { = Difference total emissions t to } \mathrm{t} \text { - } \text { divided by emissions } \mathrm{t}-1 \text { for firm, } \\ \text { Sales/Emissions } & \text { = Sales in dollars per year divided by total emissions, } \\ \text { Profit/Emissions } & \text { = Firms operating profit before tax divided by total emissions, } \\ \text { Age-Assets } & \text { = Net fixed Assets divided by Gross Fixed Assets, } \\ \text { Green } & =\text { Binary variable } 0 \text { for non-green firms, } 1 \text { for green firms, } \\ \text { Totalemsales } & \text { = Total emissions for company divided by net sales, } \\ \text { Change Sales } & =\text { Change in sales year } \mathrm{t} \text { to t }-1 \text { and } \\ \text { Profit/Sales } & =\text { Operating income divided by sales. }\end{array}$

The results indicate that the green firms had lower average emissions over both sub periods 1988-1992 and 1993-1996. For the profitability measure, green firms have higher ROS in both sub periods than do non-green firms, 1988-1992 and 1993-1996. Green firms were significantly smaller, as measured by sales, for the 1988-1992 period. The descriptive statistics also suggest a difference between green and non-green firms in generating sales and profits per pound of emissions and the age of assets in use.

Table 1: Descriptive Statistics Of Data For Green And Non-Green Firms

\begin{tabular}{|c|c|c|c|c|c|c|}
\hline & \multicolumn{3}{|c|}{ 1988-1992 } & \multicolumn{3}{|c|}{ 1993-1996 } \\
\hline Variable & Green & Non-Green & $\begin{array}{l}\text { Test of } \\
\text { Differences }\end{array}$ & Green & Non-Green & $\begin{array}{l}\text { Test of } \\
\text { Differences }\end{array}$ \\
\hline $\begin{array}{l}\text { Total } \\
\text { Emissions }\end{array}$ & $\begin{array}{l}4.4 \mathrm{E} 6 \\
10.6 \mathrm{E} 6\end{array}$ & $\begin{array}{l}17.7 \mathrm{E} 6 \\
49.9 \mathrm{E} 6 \\
\end{array}$ & $-13.3 \mathrm{E} 6 * * *$ & $\begin{array}{l}1.9 \mathrm{E} 6 \\
3.3 \mathrm{E} 6 \\
\end{array}$ & $\begin{array}{l}10.7 \mathrm{E} 6 \\
27.9 \mathrm{E} 6 \\
\end{array}$ & $-8.8 \mathrm{E} 6 * * *$ \\
\hline ROS & $\begin{array}{l}0.049 \\
0.035\end{array}$ & $\begin{array}{l}0.039 \\
0.052\end{array}$ & $0.010 * *$ & $\begin{array}{l}0.056 \\
0.036\end{array}$ & $\begin{array}{l}0.037 \\
0.051\end{array}$ & $0.019 * * *$ \\
\hline Sales & $\begin{array}{l}7.4 \mathrm{E} 9 \\
11.9 \mathrm{E} 9 \\
\end{array}$ & $\begin{array}{l}10.6 \mathrm{E} 9 \\
18.1 \mathrm{E} 9 \\
\end{array}$ & $-3.2 \mathrm{E} 9 *$ & $\begin{array}{l}9.3 \mathrm{E} 9 \\
13.6 \mathrm{E} 9 \\
\end{array}$ & $\begin{array}{l}12.0 \mathrm{E} 9 \\
23.8 \mathrm{E} 9 \\
\end{array}$ & $-2.7 \mathrm{E} 9$ \\
\hline Debt/Assets & $\begin{array}{l}0.324 \\
0.435 \\
\end{array}$ & $\begin{array}{l}0.313 \\
0.145 \\
\end{array}$ & 0.011 & $\begin{array}{l}0.245 \\
0.093 \\
\end{array}$ & $\begin{array}{l}0.316 \\
0.183 \\
\end{array}$ & $-0.071 * * *$ \\
\hline $\begin{array}{l}\text { \% Change } \\
\text { Emissions }\end{array}$ & $\begin{array}{l}-3.371 \\
29.376 \\
\end{array}$ & $\begin{array}{l}-1.176 \\
6.164 \\
\end{array}$ & -2.195 & $\begin{array}{l}2.676 \\
12.709 \\
\end{array}$ & $\begin{array}{l}-5.286 \\
36.881 \\
\end{array}$ & 2.610 \\
\hline $\begin{array}{l}\text { Sales/ } \\
\text { Emissions }\end{array}$ & $\begin{array}{l}9.8 \mathrm{E} 3 \\
19.7 \mathrm{E} 3 \\
\end{array}$ & $\begin{array}{l}4.3 \mathrm{E} 3 \\
15.8 \mathrm{E} 3 \\
\end{array}$ & $5.5 \mathrm{E} 3 * * *$ & $\begin{array}{l}60.8 \mathrm{E} 3 \\
233.1 \mathrm{E} 3 \\
\end{array}$ & $\begin{array}{l}109.9 \mathrm{E} 3 \\
922.2 \mathrm{E} 3 \\
\end{array}$ & $-49.1 \mathrm{E} 3$ \\
\hline $\begin{array}{l}\text { Profit/ } \\
\text { Emissions }\end{array}$ & $\begin{array}{l}1.4 \mathrm{E} 3 \\
2.8 \mathrm{E} 3 \\
\end{array}$ & $\begin{array}{l}.5 \mathrm{E} 3 \\
2.0 \mathrm{E} 3 \\
\end{array}$ & $0.9 \mathrm{E} 3 * * *$ & $\begin{array}{l}8.8 \mathrm{E} 3 \\
31.7 \mathrm{E} 3 \\
\end{array}$ & $\begin{array}{l}15.7 \mathrm{E} 3 \\
131.6 \mathrm{E} 3 \\
\end{array}$ & $-6.9 \mathrm{E} 3$ \\
\hline Age of Assets & $\begin{array}{l}0.563 \\
0.078 \\
\end{array}$ & $\begin{array}{l}0.545 \\
0.096 \\
\end{array}$ & $0.018^{*}$ & $\begin{array}{l}0.517 \\
0.083 \\
\end{array}$ & $\begin{array}{l}0.511 \\
0.085 \\
\end{array}$ & 0.006 \\
\hline Totalemsales & $\begin{array}{l}1.1 \mathrm{E}-3 \\
2.1 \mathrm{E}-3 \\
\end{array}$ & $\begin{array}{l}3.8 \mathrm{E}-3 \\
7.6 \mathrm{E}-3 \\
\end{array}$ & $-2.7 \mathrm{E}-3 * * *$ & $\begin{array}{l}0.5 \mathrm{E}-3 \\
0.9 \mathrm{E}-3 \\
\end{array}$ & $\begin{array}{l}2.3 \mathrm{E}-3 \\
4.4 \mathrm{E} 3 \\
\end{array}$ & $-1.8 \mathrm{E}-3 * * *$ \\
\hline $\begin{array}{l}\text { Change in } \\
\text { Sales }\end{array}$ & $\begin{array}{l}14.0 \mathrm{E} 6 \\
826.2 \mathrm{E} 6 \\
\end{array}$ & $\begin{array}{l}870.7 \mathrm{E} 6 \\
1,032.4 \mathrm{E} 6 \\
\end{array}$ & $-856.7 \mathrm{E} 6$ & $\begin{array}{l}12.6 \mathrm{E} 6 \\
1,144.7 \mathrm{E} 6 \\
\end{array}$ & $\begin{array}{l}108.6 \mathrm{E} 6 \\
2,144.3 \mathrm{E} 6 \\
\end{array}$ & $-96.4 \mathrm{E} 6$ \\
\hline Profit/Sales & $\begin{array}{l}0.142 \\
0.050 \\
\end{array}$ & $\begin{array}{l}0.134 \\
0.069 \\
\end{array}$ & 0.008 & $\begin{array}{l}0.151 \\
0.046 \\
\end{array}$ & $\begin{array}{l}0.140 \\
0.060 \\
\end{array}$ & 0.011 \\
\hline
\end{tabular}

This table shows descriptive statistics of data for green and non-green firms across sub-periods corresponding to the First Bush Presidential Administration and the Clinton Administration. The first figure in each cell is the mean, the second figure in each cell is the standard deviation. In the test for differences column, the mean difference between green firms and non-green firms is reported. The test of dif- 
The analysis continues with a series of multivariate tests. The multivariate analysis begins by identifying variables related to the total emissions of the firm. Prior research indicates that size may be a factor in level of environmental disclosure (Walden and Schwartz 1997; Trotman and Bradley 1981). Larger firms are associated with increased environmental disclosures. Rockness et al. (1985) find that larger firms are more likely to dispose of chemical waste on site, rather than shipping it off to other locations. Based on this literature larger firms are expected to emit more than smaller firms. Industry level differences are reported in the literature concerning environmental disclosures, profitability, and pollution impact (Walden and Schwartz 1997; Russo and Fouts 1997). Industries such as chemical, pulp and paper are known for higher levels of pollution. Russo and Fouts (1997) find the greater the emissions firms send to hazardous waste sites, the older the asset base. Since technological developments have increased the efficiency of newer machinery, examining the relationship between assets and emissions may help us understand whether firms invest in machinery that decreases their overall impact on the environment. We expect that firms with newer assets will generate lower emissions than firms with older assets. Firms with favorable environmental reputations have made a long-term commitment to be environmentally proactive (Prokop 1992). Many studies find a correlation between firms with favorable environmental reputation and increased pollution control efforts (Russo and Fouts 1997; Prokap 1992). Based on this literature, it is hypothesized that the size of the firm, the age of assets, and the industry that the firm operates within impact the amount of emissions released by a firm and estimate the following equation with the notations above each variable indicating the hypothesized sign:

$(-)$

$(-) \quad(+)$

(?)

(?)

Model: Total Emissions $=\beta_{o}+\beta_{1}$ Green $+\beta_{2}$ Age-Assets $+B_{3}$ Sales $+B_{4}$ Industry $+B_{5}$ Year $+\varepsilon$

where:

Industry = Dummy variables by 2-digit SIC Industry grouping,

Year = Dummy variables for years 1989-1996

All Other Variables are as previously defined

The results are presented in Table 2. Similar to the univariate results, the multivariate results are as expected for the overall time period. The variable green is binary ( 1 for green firms and 0 for non-green firms). The coefficient on green is negative and significant for the overall time period. However, for the 1988-1992 time period the relationship is not significant. For the 1993-1996 time period, the relationship is negative and significant. These results indicate that early in the TRI reporting period, emission levels for firms in the sample were not easily distinguishable based on their environmental reputation. This may be a function of firms with unfavorable environmental reputations reducing emissions greatly at the outset of the publicly available TRI information. These firms may have used slack in their organization to eliminate emissions with little or no effect on operations. In contrast, over the 1993-1996 period, firms with favorable environmental reputations may have already developed programs to reduce their pollution stream over time. Firms with favorable environmental reputations continued to reduce emissions, perhaps successfully integrating pollutions issues into their strategic management process. The coefficient on green is negative and significant. These green firms were not implementing quick-fix solutions but had developed long term plans to reduce emissions.

The analysis continues by examining changes in firms' total emissions. If reputations are assigned equitably by individuals and agencies it can reasonably be expected that firms with favorable environmental reputations should be more successful in reducing emissions than firms with unfavorable environmental reputations. A firm with a favorable environmental reputation will have a proactive approach to pollution control and will move aggressively to eliminate waste and related emissions (Sullivan 1992). Therefore, the emissions are likely to decrease more over time if a firm is green than if it is non-green. 
Table 2: Regression Of Total Emissions On Environmental Reputation Of Firm, Age Of Assets, Size, And Year.

\begin{tabular}{|l|l|l|l|l|}
\hline Variable & Predicted Sign & $\begin{array}{l}\text { Full Sample } \\
1988-1996\end{array}$ & $\begin{array}{l}\text { Sub-Period } \\
1988-1992\end{array}$ & $\begin{array}{l}\text { Sub-Period } \\
1993-1996\end{array}$ \\
\hline Intercept & NA & $\begin{array}{l}24,975,212^{* *} \\
(2.15\end{array}$ & $\begin{array}{l}40,327,225^{* *} \\
(2.21)\end{array}$ & $\begin{array}{l}6,022,595 \\
(0.54)\end{array}$ \\
\hline Green & - & $\begin{array}{l}-7,629,987 * * \\
(-2.03)\end{array}$ & $\begin{array}{l}-5,667,372 \\
(-1.02)\end{array}$ & $\begin{array}{l}-6,690,189 * * \\
(1.96)\end{array}$ \\
\hline Age-Assets & - & $-25,918,415^{*}$ & $-72,856,576^{* * *}$ & $4,424,590$ \\
& & $(-1.50)$ & $(-2 . .56)$ & $(0.22)$ \\
\hline Sales & + & $360.15^{* * *}$ & $\begin{array}{l}791.04 * * * \\
(4.78)\end{array}$ & $\begin{array}{l}228.42^{* * *} \\
(2.98)\end{array}$ \\
\hline Industry & $(4.33)$ & Not Reported & Not Reported \\
\hline Year & $?$ & Not Reported & Not Reported & Not Reported \\
\hline Adjusted R & $?$ & Not Reported & 0.182 & 0.103 \\
\hline Sample Size & & 0.115 & 300 & 240 \\
\hline
\end{tabular}

This table identifies variables that explain the total emissions of the firm. The first figure in each cell is the regression coefficient. The second figure in each cell is the t-statistic. $* * * * * *$ indicate significance at the $0.01,0.05$, and 0.10 levels respectively for a one tailed test where the sign is predicted, and for a two-tailed test otherwise.

The variables identified as related to total emissions in the previous model are used as control variables in this model. In addition, changes in emissions may be affected by how efficient a firm was when the TRI data became available (Lanen, 1999). Firms that produced lower emissions at the start of the TRI reporting had less room for easy reduction of emissions than firms with higher emissions. This effect is estimated by including total emissions divided by sales as an independent variable in the model. The higher this number in 1988, the less effective a firm was initially in controlling emissions. To examine the relationship between change in emissions and whether a firm is classified as green, we estimate the following model:
$(-)$
(?)
$(+)$
$(-)$
$(+)$

Model: $\%$ Change Emissions $=\beta_{o}+\beta_{1}$ Green $+B_{2}$ Totalemsales $+B_{3}$ ChangeSales $+B_{4}$ Age-Assets $+B_{5}$ Sales +

(?) (?)

$B_{6}$ Industry $+B_{7}$ Year $+\varepsilon$

The results are presented in Table 3. The coefficients on the green variable and the control variables are not significant. These results do not support the hypothesis that green firms had larger reductions in emissions, suggesting that green firms may have been improving their environmental performance long before the TRI data become available. If so, they might not have needed as large decreases when the TRI first started reporting in 1987. It is also possible that the organizational slack available to non-green firms was sufficient to allow these firms to reduce emissions as much or more than green firms over the time period analyzed.

If green firms operate differently than non-green firms, there should be identifiable differences in economic indicators, such as profitability. In this section, the relationship between profitability and the amount that firms emit are examined. Several studies have examined the relationship between economic performance and environmental performance (Russo and Fouts 1997; Gilley et al. 2000). We extend these models as discussed earlier.

If firms can externalize the cost of polluting, it can be expected that firms that pollute more will be more profitable. Without accepting the additional costs associated with polluting, firms will be in a position to emit more and avoid associated pollution control expenditures. Therefore, firms with higher emissions should have higher profits. Profits should also relate to level of sales, industry, and interest payments. We examine this relationship by estimating the following equation: 
TABLE 3: Regression Of Change In Emissions On Environmental Reputation Of Firm, Emissions Per Sales Dollar, Change In Sales, Age Of Assets, Size, Industry And Year.

\begin{tabular}{|l|l|l|l|l|}
\hline Variable & Predicted Sign & $\begin{array}{l}\text { Full Sample } \\
1988-1996\end{array}$ & $\begin{array}{l}\text { Sub-Period } \\
1988-1992\end{array}$ & $\begin{array}{l}\text { Sub-Period } \\
1993-1996\end{array}$ \\
\hline Intercept & NA & -18.55 & -13.20 & $(-1.07)$ \\
& & $(-1.30)$ & -0.82 & 3.05 \\
& $-0.17)$ \\
\hline Green & - & 3.02 & $(-0.26)$ & 4.71 \\
& & $(0.82)$ & -0.00004 & $(0.92)$ \\
\hline Totalemsales & $?$ & -0.00005 & $(-0.16)$ & 0.00008 \\
& & $(-0.12)$ & -0.00013 & $(0.07)$ \\
\hline ChangeSales & + & -0.00016 & $(-0.13)$ & -0.00025 \\
& & $(-0.15)$ & 30.13 & $(-0.16)$ \\
\hline Age-Assets & - & 36.79 & $(1.56)$ & -6.31 \\
& & $(1.59)$ & 0.00002 & $(-0.19)$ \\
\hline Sales & + & 0.000049 & $(-0.16)$ & 0.00007 \\
& & $(0.41)$ & Not Reported & Not Reported \\
\hline Industry & $?$ & Not Reported & Not Reported & Not Reported \\
\hline Year & $?$ & Not Reported & 0.0919 & 0.0851 \\
\hline Adjusted R & & 0.098 & 300 & 240 \\
\hline Sample Size & & 540 & & \\
\hline
\end{tabular}

This table shows the results of the test that green firms will reduce emissions by more than non-green firms. The first figure in each cell is the regression coefficient. The second figure in each cell is the $\mathrm{t}$-statistic. ***,*** indicate significance at the $0.01,0.05$, and 0.10 levels respectively for a one tailed test where the sign is predicted, and for a two-tailed test otherwise.

$(+)$

$(-)$

$(+)$

$(+)$

(?)

(?)

Model: $R O S=\beta_{o}+\beta_{1}$ Totalemissions $+\beta_{2}$ DebttoAssets $+B_{3}$ Age-Assets $+B_{4}$ Sales $+B_{5}$ Industry $+B_{6}$ Year $+\varepsilon$

The use of return on sales (ROS) as a measure of profitability is well established in the literature (Ittner and Larcker 1997). Total emissions is measured as the overall emissions in pounds for a firm in a given year. Total debt to assets is included to control for potential differences in ROS due to interest expense. Age of assets is included to control for the effect of new machinery on profitability. Net sales control for variation in ROS due to size effects since the size of a firm may influence ROS through economies of scale. Industry is included to control for differences in ROS due to industry effects (Ittner and Larcker 1997).

The results are presented in Table 4. The coefficient on total emissions is not significantly associated with ROS. The coefficient on the debt to assets ratio is negative and significant and the coefficient on age of assets is positive and significant. The coefficients on the control variables are consistent with predictions, the debt to asset ratio representing higher interest expense which affects profitability negatively, while the newer assets increase operating efficiency, which in turn decreases operating costs, thereby increasing profitability.

Contrary to predictions, the coefficient on total emissions is not significant. Accordingly, a sensitivity analysis is conducted for sub time periods which indicated some differences between the 1988-1992 and 1993-1996 time periods. The coefficient on total emissions is positive and significant for the 1988-1992 period as predicted. However, for the 1993-1996 time period the coefficient is not significant. This indicates that firms emitting more during the 1998-1992 period were more likely to be more profitable. With less federal control they were able to emit without having to internalize the costs of their pollution. Apparently they outperformed firms that were actively controlling their emissions. In the 1993-1996 period, there is no relationship between total emissions and ROS. This could be the result of increased federal regulations designed to minimize the effects of firms choosing to emit in a pro-industry state over an environmental state. As all firms generally have lowered their emissions, it is possible that much of the slack was used up in earlier periods, with emissions as an aggregate measure no longer impacting profitability. 
The debt to assets ratio was negative and significant in both periods as predicted. The increased level of interest payments, as proxied for by debt to assets, will negatively impact a firm's profitability. The coefficient on age of assets was not significant in the 1988-1992 period, but was positive and significant in the 1993-1996 time period. The results for the latter period indicated that firms investing in new assets are more profitable. The newer assets may be more efficient, either by streamlining manufacturing processes or reducing direct labor. Case studies examining the types of equipment purchased by various firms could shed some light on where and how the cost savings originate. ROE and ROA were substituted for ROS in the regression (results not reported) to perform sensitivity analysis. The results indicated only slight differences in significance levels, with none changing from significant to non-significant or vice versa, signaling a robustness across the profitability measures.

Table 4: Regression Of Firm Profitability On Total Emissions, Debt To Assets, And Control Variables For Age Of Asset Base, Size, And Industry.

\begin{tabular}{|c|c|c|c|c|}
\hline Variable & Predicted Sign & $\begin{array}{l}\text { Full Sample } \\
1988-1996\end{array}$ & $\begin{array}{l}\text { Sub-Period } \\
1988-1992\end{array}$ & $\begin{array}{l}\text { Sub-Period } \\
1993-1996\end{array}$ \\
\hline Intercept & NA & $\begin{array}{l}0.0425 \\
(1.11) \\
\end{array}$ & $\begin{array}{l}0.0411 \\
(0.75)\end{array}$ & $\begin{array}{l}-0.0134 \\
(-0.62)\end{array}$ \\
\hline Total Emissions & + & $\begin{array}{l}3.877 \mathrm{E}-11 \\
(0.20)\end{array}$ & $\begin{array}{l}1.7092 \mathrm{E}-9 * * \\
(1.93)\end{array}$ & $\begin{array}{l}7.41 \mathrm{E}-11 \\
(0.42)\end{array}$ \\
\hline Debt/Assets & - & $\begin{array}{l}-0.033 * * * \\
(-0.32) \\
\end{array}$ & $\begin{array}{l}-0.0137^{*} \\
(-1.41) \\
\end{array}$ & $\begin{array}{l}-0.1358 * * * \\
(-6.63) \\
\end{array}$ \\
\hline Age-Assets & + & $\begin{array}{l}0.076^{* * *} \\
(1.79) \\
\end{array}$ & $\begin{array}{l}0.082 \\
(1.06) \\
\end{array}$ & $\begin{array}{l}0.1207 * * * \\
(3.01)\end{array}$ \\
\hline Sales & + & $\begin{array}{l}-2.48 \mathrm{E}-8 \\
(-0.13) \\
\end{array}$ & $\begin{array}{l}-5.629 \mathrm{E}-7 * \\
(-1.46)\end{array}$ & $\begin{array}{l}-8.344 \mathrm{E}-8 \\
(-0.55)\end{array}$ \\
\hline Industry & $?$ & Not Reported & Not Reported & Not Reported \\
\hline Year & $?$ & Not Reported & Not Reported & Not Reported \\
\hline Adjusted $\mathrm{R}^{2}$ & & 0.216 & 0.289 & 0.364 \\
\hline Sample Size & & 540 & 300 & 240 \\
\hline
\end{tabular}

This table shows the results of the test that firm profitability is related to the total emissions of the firm. The first figure in each cell is the regression coefficient. The second figure in each cell is the $\mathrm{t}$-statistic. ******* indicate significance at the $0.01,0.05$, and 0.10 levels respectively for a one tailed test where the sign is predicted, and for a two-tailed test otherwise.

If environmental rankings appropriately assess firms' abilities to limit their impact on the environment, then firms identified as green may be able to lower emissions without reducing sales or profitability. Green firms may not match the profitability of non-green firms dollar for dollar, but they may be more efficient in generating sales and profits per pound of emissions generated. Utilizing TQEM and other pollution/cost reducing measures, green firms should be able to generate more sales/profit per pound of emissions. As discussed previously, a green reputation may lead to higher sales. Accordingly, sales and profit per pound of emission should be higher for green firms than non-green firms. We test this contention by estimating the following model

$(-)$

$(+)$

$(+)$

(?)

Model: Sales/Emissions $=\beta_{o}+\beta_{1}$ Green $+\beta_{2}$ DebttoAssets $+B_{3}$ Age-Assets $+B_{4}$ Sales $+B_{5}$ Industry $+B_{6}$ Year $+\varepsilon$

The results are presented in Table 5. For the overall time period, firms with favorable environmental reputations have lower sales per pound of emissions that firms with unfavorable environmental reputation. This result is not as predicted. Further analysis by sub times period provides more insight into this relationship. When the overall time period is divided into two sub periods, for the 1988-1992 sub-period, green has a positive and significant coefficient as predicted. This indicates that firms with favorable environmental reputations have higher sales per pound of emission than firms with unfavorable environmental reputation. The environmentally proactive firms are able to maintain or increase sales while maintaining or lowering emissions. This behavior is consistent with building a positive environmental reputation. The r-square for this model was 0.281 . 
In the 1993-1996 period, the coefficient on the green variable is negative and significant. This indicates that firms with unfavorable environmental reputations actually have higher sales per pound of emission than firms with positive environmental reputations. The increase in federal environmental regulations may drive the change in nongreen firm behavior. The dramatic changes in sales per pound of emission by non-green firms could also be related to the amount of organizational slack present in non-green firms' production processes. When increased environmental regulations made it difficult to emit freely in any state, non-green firms may have used slack present in the pollution control system to eliminate emissions without having to impact sales. This period (1993-1996) was also a period when sales and profits increased throughout the economy. Green firms controlled emissions aggressively earlier than non-green firms, and therefore may not have had the slack available for dramatic improvements in emissions for the later time period. The r-square for the later time (1993-1996) period was 0.084, representing substantially less variation explained than in the earlier time period (1988-1992). This could be a result of other unknown factors affecting sales per pound of emissions.

For the 1988-1992 time period the variable used to control for size, net sales, has a positive and significant coefficient. However, in the 1993-1996 time period the coefficients on sales and the other variable are insignificant. This finding is interpreted as indicating that initially, larger firms were more efficient in generating higher sales dollars per pound of emissions than smaller firms. Towards that end of the time considered, small firms may have been able to increase their efficiency, generating sales to emissions ratios similar to the large firms.

Table 5: Regression Of Firm Sales Divided By Emissions On Environmental Reputation Of Firm And Control Variables For Interest Expense, Age Of Asset Base, Size, Industry And Year.

\begin{tabular}{|c|c|c|c|c|}
\hline Variable & Predicted Sign & $\begin{array}{l}\text { Full Sample } \\
1988-1996 \\
\end{array}$ & $\begin{array}{l}\text { Sub-Period } \\
1988-1992\end{array}$ & $\begin{array}{l}\text { Sub-Period } \\
1993-1996 \\
\end{array}$ \\
\hline Intercept & NA & $\begin{array}{l}0.3514 \\
(0.71)\end{array}$ & $\begin{array}{l}0.031 * * * \\
(2.617)\end{array}$ & $\begin{array}{l}0.3571 \\
(0.87\end{array}$ \\
\hline Green & + & $\begin{array}{l}-0.1286^{* *} \\
(-1.68)\end{array}$ & $\begin{array}{l}0.0083 * * \\
(2.70)\end{array}$ & $\begin{array}{l}-0.163^{*} \\
(1.43)\end{array}$ \\
\hline Debt/Assets & - & $\begin{array}{l}0.0574 \\
(0.40)\end{array}$ & $\begin{array}{l}0.000625 \\
(0.30)\end{array}$ & $\begin{array}{l}0.1176 \\
(0.30)\end{array}$ \\
\hline Age-Assets & + & $\begin{array}{l}-0.547 \\
(-1.11) \\
\end{array}$ & $\begin{array}{l}-0.0210 \\
(-1.26) \\
\end{array}$ & $\begin{array}{l}-0.5778 \\
(-0.78) \\
\end{array}$ \\
\hline Sales & + & $\begin{array}{l}1.2642 \mathrm{E}-6 \\
(0.64)\end{array}$ & $\begin{array}{l}1.7821 \mathrm{E}-7 * * * \\
(2.24)\end{array}$ & $\begin{array}{l}1.5079 \mathrm{E}-6 \\
(0.55)\end{array}$ \\
\hline Industry & $?$ & Not Reported & Not Reported & Not Reported \\
\hline Year & $?$ & Not Reported & Not Reported & Not Reported \\
\hline Adjusted $\mathrm{R}^{2}$ & & 0.069 & 0.281 & 0.084 \\
\hline Sample Size & & 540 & 300 & 240 \\
\hline
\end{tabular}

This table shows the results of the test that sales per pound of emissions differs between green and non-green firms. The first figure in each cell is the regression coefficient. The second figure in each cell is the t-statistic. ***,**** indicate significance at the $0.01,0.05$, and 0.10 levels respectively for a one tailed test where the sign is predicted, and for a two-tailed test otherwise.

Finally, we test whether green firms are more efficient in generating profit per pound of emission than nongreen firms. If green firms are successful in reducing emissions, it is possible that this effect is caused by successful cost reducing initiatives. To test this hypothesis, we estimate the following equation.

$(+)$

Model: Profit/Emissions $=\beta_{o}+\beta_{l}$ Green $+\beta_{2}$ DebttoAsset
$(-)$

$(+)$

$(+)$

(?)

$(?)$

The results are presented in Table 6. The results are counter to expectation, firms with favorable environmental reputations have lower profit per pound of emission than firms with unfavorable environmental 
reputations. The coefficient on green was negative and significant. This result is further analyzed below in the sensitivity analysis.

The sensitivity analysis indicates a change over time in the relationship between firms and profit per pound of emission. In the 1988-1992 time period a positive and significant relationship arises between profit per pound of emission and being green. This indicates that early in the period when the TRI data became available, firms with favorable environmental reputations were more efficient in generating profit while controlling emissions. During this period of stronger state control over the environment, the green firms were actively responding to the environmental regulations while firms with unfavorable environmental reputations were not as effective in producing profit while controlling emissions. The non-green firms may have sought out states where environmental regulations were less stringent and therefore less important in the firms' operating decision process.

The coefficient on age of assets is negative in this regression model. This is not as expected since newer equipment was predicted to have a positive relationship with profit per pound of emission. It is possible that firms with higher age of assets ratios had significantly higher depreciation expense that impacted the profitability of the firm and overshadowed any productivity improvements that may have been present. This relationship did not continue in the later time period. The coefficient on size was positive and significant. In the early part of the TRI reporting period, larger firms were associated with higher profit per pound of emissions. The significance of sales in the early period indicates that larger companies were more efficient in generating profit per pound of emissions and that certain industries were more efficient as well. Economies of scale would provide larger firms with an early advantage that smaller firms could overcome through strategic planning. This relationship did not continue in the later time period.

The regression model for the 1988-1992 time period has an r-square of 0.326. In the later time period (1993-1996) it is 0.087. This change in amount of variation captured indicates changes in firm behavior. Control variables that explained more in the earlier time period no longer explain the same level of variation in the later time period. Further study is needed about the effects of the change in regime at the White House and the accompanying reversal in environmental policy to identify new variables affecting the environmental behavior of firms.

Table 6: Regression Of Firm Profit Divided By Emissions On Environmental Reputation Of Firms And Control Variables For Interest Expense, Age Of Asset Base, Size, Industry And Year.

\begin{tabular}{|c|c|c|c|c|}
\hline Variable & Predicted Sign & $\begin{array}{l}\text { Full Sample } \\
1988-1996 \\
\end{array}$ & $\begin{array}{l}\text { Sub-Period } \\
1988-1992 \\
\end{array}$ & $\begin{array}{l}\text { Sub-Period } \\
1993-1996 \\
\end{array}$ \\
\hline Intercept & NA & $\begin{array}{l}0.0522 \\
(0.74) \\
\end{array}$ & $\begin{array}{l}0.00612 * * * \\
(3.10)\end{array}$ & $\begin{array}{l}0.0519 \\
(0.89)\end{array}$ \\
\hline Green & + & $\begin{array}{l}-0.019^{*} \\
(-1.70) \\
\end{array}$ & $\begin{array}{l}0.0013 \text { *** } \\
(2.72)\end{array}$ & $\begin{array}{l}-0.0234 \\
(-1.44) \\
\end{array}$ \\
\hline Debt/Assets & - & $\begin{array}{l}0.0081 \\
(0.40)\end{array}$ & $\begin{array}{l}0.00079 \\
(0.22)\end{array}$ & $\begin{array}{l}0.00163 \\
(0.29)\end{array}$ \\
\hline Age-Assets & + & $\begin{array}{l}-0.0811 \\
(-1.16) \\
\end{array}$ & $\begin{array}{l}-0.0056 * * \\
(-2.05)\end{array}$ & $\begin{array}{l}-0.085 \\
(-0.80) \\
\end{array}$ \\
\hline Sales & + & $\begin{array}{l}1.8904 \mathrm{E}-7 \\
(0.67)\end{array}$ & $\begin{array}{l}\text { 4.1332E-8*** } \\
(3.20)\end{array}$ & $\begin{array}{l}2.1862 \mathrm{E}-7 \\
(0.56)\end{array}$ \\
\hline Industry & $?$ & Not Reported & Not Reported & Not Reported \\
\hline Year & $?$ & Not Reported & Not Reported & Not Reported \\
\hline Adjusted $\mathrm{R}^{2}$ & & 0.072 & 0.326 & 0.087 \\
\hline Sample Size & & 540 & 300 & 240 \\
\hline
\end{tabular}

This table presents the results of the test that green firms are more efficient in generating profit than non-green firms. The first figure in each cell is the regression coefficient. The second figure in each cell is the $\mathrm{t}$-statistic. ***,**** indicate significance at the $0.01,0.05$, and 0.10 levels respectively for a one tailed test where the sign is predicted, and for a two-tailed test otherwise. 


\section{Concluding Comments}

Public concern for the environment is forcing firms to change their business practices. Some firms are taking a pro-active approach to protecting the environment while other firms are taking a reactive approach. Understanding firm behavior in the environmental protection area is important for accounting professionals. Firms are increasingly being evaluated, both internally and externally, based on non-financial measures (Kaplan and Norton 1996). Non financial measures such as the emissions data from the EPA's TRI database are providing stakeholders with information from non-traditional sources. The accounting professional is the logical choice to assimilate and disseminate the non-financial date in a usable form (Ilinith et al. 1998).

This study is the first to use emissions information from a non-financial source to analyze differences between firms to changes in regulatory environment. This paper also advances the literature on several fronts. First, it extends the literature on the general reputation of firms on financial performance by simultaneously incorporating non-financial data and by focusing on the environmental reputation of firms. Second, we extend the studies of environmental reputation by utilizing a different measure of green or non-green. Third, we extend those studies that have utilized the TRI database by extending the time frame of the analysis, examining multiple industries and incorporating total emissions data rather than only one type of emissions. Finally, the sample is segregated into two sub-samples that correspond with the current Presidential Administration. By doing so, the impact changes in regulatory regime on firm behavior are examined.

The results indicate that green firms have lower average emissions, higher Return on Sales (ROS), are smaller, and are more profitable per pound of emission. The results indicate that green firms have lower total emissions after controlling for the effects of firm size, age of assets and industry. Those firms classified as green firms continued to reduce their emissions throughout the period of study, while non-green firms only adjusted their emissions after they were required to disclose their emissions through the TRI. The data indicates that green firms did not have larger reductions in emissions than non-green firms during the sample period, suggesting that the green firms had large reductions in emissions prior to 1988. Further, firms with green reputations were more profitable during the first sub-period but were less profitable during the second sub-period. This finding suggests that with less federal control, firms were able to emit more without having to internalize the cost of their pollution. Finally, the results indicate that in the 1998-1992 sub-period, green firms had higher sales per pound of emissions while in the 1993-1996 sub-period, non-green firms had higher sales per pound of emissions. This evidence suggests that the increase in federal regulations drove non-green firms to change their behavior. Overall, this paper provides clear evidence that green firms behave markedly different, have different firm characteristics, and react to changes in regulatory regime in different ways than their non-green counterparts.

\section{References}

1. Aupperle, K., a. Carroll, and J. Hatfield. 1985. "An Empirical Examination of the Relationship between Corporate Social Responsibility and Profitability”, Academy of Management Journal 28 (2): 446-463.

2. Bhat, V. 1998. Total Quality Environmental Management: an ISO 1400 approach. Westport CT: Greenwood Publishing.

3. BusinessWeek. 1990. "The Greening of Corporate America", April 23. pp. 96-103.

4. Domini Social Investments. 2000. "DEEF-The Social Criteria", Available at: http://www.domini.com/SocCriteria.html.

5. Gilley, K., D. Worrell and A. El-Jelly. 2000. "Corporate Environmental Initiatives and Anticipated Firm Performance. The Differential Effects of Process-Driven Versus Product-Driven Greening Initiatives", Journal of Management 26 (6): 1199-1216.

6. Herreman, I., P. Akathaporn and M. McInnes. 1993. "An Investigation of Corporate Social Responsibility Reputation and Economic Performance", Accounting, Organizations and Society 18 (7/8): 587-604.

7. Ilinitch, A., N. Soderstrom, and T. Thomas. 1998. "Measuring corporate environmental performance", Journal of Accounting and Public Policy 17: 383-408.

8. Ittner C., and D. Larcker. 1997. "The Performance Effects of Process Management Techniques", Management Science 43. (4). 522-534. 
9. Jaggie B., and M. Freedman. 1992. "An Examination of The Impact of Pollution Performance on Economic and Market Performance: Pulp and Paper Firms", Journal of Business Finance and Accounting 19(5): 697-714.

10. Kaplan, R. and D. Norton. 1996. The Balanced Scorecard. Boston, MA: Harvard Business School Press.

11. Lanen, W. 1999. "Waste Minimization at 3M Company: A Field Study in Non-Financial Performance Measurement", Journal of Management Accounting Research 11: 29-43.

12. Prokop, M. 1992. Managing to be Green. San Diego, California: Pfeiffer \& Co.

13. Rockness, J. Schelachter, P. and H. Rockness. 1986. "Hazardous Waste Disposal, Corporate Disclosure, and Financial Performance in the Chemical Industry", Advances in Public Interest Accounting 1: 167-191.

14. Russo, M. and P. Fouts. 1997. "A Resource-Based Perspective on Corporate Environmental Performance and Profitability", Academy of Management Journal 40 (3): 534-559.

15. Shrivastava, P. 1996. Greening Business: Profiting the Corporation and the Environmental. Cincinnati, $\mathrm{OH}$ : Thomson Executive Press.

16. Shrivastava, P. 1995. "Environmental Technologies and Competitive Advantage", Strategic Management Journal 16: 183-200.

17. SRI World Group Inc. 2000. "Introduction to Socially Responsible Investing." Available at: http:///www.socialfunds.com/article1.cgi.

18. Standard and Poors. 1999. Compustat database. Englewood, CO.

19. Sullivan, T. 1992. The Greening of American Business. Rockville, Maryland: Government Institute, Inc.

20. Thomas, S.T. 1995. Facility Manager's Guide to Pollution Prevention and Waste Minimization. Washington D.C: BNA Books.

21. Trotman, K. and G. Bradley. 1981. "Associations Between Social Responsibility Disclosure and Characteristics of Companies", Accounting, Organizations and Society 6 (4): 355-362.

22. Walden, W. and B. Schwartz. 1997. "Environmental Disclosures and Public Policy Pressure", Journal of Accounting and Public Policy 16: 125-154. 
Notes 